Lehti L., P. Peltonen, S. Routarinne, V. Vaakanainen \& V. Virsu (toim.) 2018. Uusia lukutaitoja rakentamassa - Building new literacies. AFinLAn vuosikirja 2018. Suomen soveltavan kielitieteen yhdistyksen julkaisuja n:o 76. Jyväskylä. s. 41-60.

\title{
Language teacher perceptions and practices of digital literacy in Finnish higher education
}

Digital literacy and digitalization have rapidly entered curriculum planning as key development targets in Finnish higher education, and consequently, also in the teaching and learning of languages and communication. For language teachers, this creates new development possibilities but also challenges, as new working methods and proficiencies need to be embraced. In this paper we focus on teacher perspectives of and practices in digital literacy and seek to identify the development needs they have and the challenges they face. Our study shows that there is a high level of interest in digital issues in language and communication teaching in Finland. Teachers are encouraged to include digital elements in their teaching. However, teachers need support and have varied needs in developing digipedagogical skills. The results of our study form the basis for a national-level strategy for furthering the digital literacy of language and communication teachers in higher education at personal, organizational and national levels.

Keywords: digital literacy, digitalization, language learning, higher education Asiasanat: digitaalinen lukutaito, digitalisaatio, kielen oppiminen, korkeakoulutus 


\section{Introduction}

In this paper, we discuss digital literacy and digitalization in the teaching and learning of languages and communication in Finnish higher education. These two concepts have rapidly entered curriculum planning in Finnish higher education, and consequently, also in the teaching and learning of languages and communication. For language teachers in higher education, this creates exciting and motivating development opportunities but also for many, pressure to move away from existing comfort zones. Teachers need to update their pedagogical thinking to include digital literacy and, consequently, to be able to understand the digital needs of students in the learning of languages.

The Finnish higher education system consists of 14 universities and 23 universities of applied sciences. As a mandatory part of Bachelor's degree studies in both universities and universities of applied sciences, students need to show a defined proficiency in the two national languages of Finnish and Swedish, and in at least one foreign language. This is stipulated by the Universities Act (2009) and Universities of Applied Sciences Act (2014). The current development targets in higher education aim to improve the quality of education by rethinking education content, teaching methods, learning environments and the competence of teachers, as well as increasing cooperation. In addition, there is a special focus on digitalization (Ministry of Education and Culture 2018).

Within higher education institutions, several projects have been instigated that attempt to apply these aims, and two national projects were created to focus specifically on the teaching and learning of languages and communication: 2digi and DIGIJOUJOU. The 2digi project (2018) is a national three-year (2017-2019) project of FINELC (2018), the network of Finnish university language centres. The project consists of 26 teachers and a steering group of 6 members from various university language centres. Nelson is coordinating the 2digi project and is similarly a member of the steering group. The aim of this work is to enhance digital literacy and its implementation in the learning of languages and communication. The 2digi project aims to give tools to teachers to enable them to better understand digital literacy and digitalization, and also to examine how these can be an essential part of the development of teaching in a way that is meaningful both for the teacher and for the student.

The DIGIJOUJOU project (2018) is a national three-year (2017-2019) project financed by the Ministry of Education and Culture. The project has 52 teachers and a steering group of 12 members from 4 universities and 8 universities of applied sciences (Juurakko-Paavola and Rontu are coordinating the DIGIJOUJOU project and are members of the steering group). Consequently, the project crosses over the boundaries between universities and universities of applied sciences. The project focuses on the national languages of Finnish and Swedish, but also aims at providing 
learning models that are both applicable to, and promote the development of learning in other languages. The goals of the DIGIJOUJOU project are to support the development of the curriculum towards 'digipedagogical' learning solutions, develop flexible study paths and enhance national networking and teacher collaboration. By 'digipedagogical' learning solutions we refer to systematic choices of new technologies and applications based on pedagogical criteria: Why use this technology? To whom and to which purposes does this technology fit? Where, when and how should the technology be used? (Stanley 2013: 4-5; Walker \& White 2013: 145; Stickler \& Hampel 2015: 68).

The aim of this study is to gain an overview of teacher perspectives of digital literacy and to identify the development needs and the challenges teachers face. In the study, we combine the results of two surveys conducted within the two different projects on digitalisation, reported in this article. We work with a number of research questions: 1) Do teachers believe a digital element in their teaching to be important? 2) What digital devices do they use in their teaching? 3) How far has digital literacy been adopted in curricula development? 4) Do teachers know what digital literacy is, and if they do, what do they think it is? 5) What skills do teachers have at present and what are their development needs for the future? In this paper, we start by defining the central concept of digital literacy before presenting our methodology. Our results elucidate five areas of teacher perception and practice in digital literacy and we conclude with a variety of suggestions for future development and practice of digitalization in language centre teaching.

\section{Theoretical background}

The theoretical background focuses on the concept of digital literacy. Digital literacy provides a working framework by which to study digitalization and the digital environment in education, and how teachers both understand and practice digitalization.

\subsection{Defining digital literacy}

The literature behind the concept of digital literacy is broad, diverse and ultimately can be confusing in its overlapping use of terminology and conceptualizations. The breadth of this literature is matched by the ubiquity of the digitalization process in higher education over the last twenty years or more.

Digital literacy is first and foremost a core 21st century skill (Binkley et al. 2012) required in the workplace of the future (Davies et al. 2011) and is one of the six "drivers of change" (2011: 3) that will change the working landscape. Digital literacy is also recognized as a key competence by the European Union (Ala-Mutka 2011: 
15). More recently, the World Economic Forum (2016) also singled out the rise of technology as a driver of change.

The concept of digital literacy as it is currently understood was introduced by Gilster (1997): he redefined literacy to focus on the digital environment, "literacy for the digital age" (Gilster 1997, cited in Bawden 2008: 28). Thus, to be literate in the 21 st century, Gilster noted the need to have a grasp of core digital skills. These included "knowledge assembly", building a "reliable information hoard" from diverse sources, retrieval skills, plus "critical thinking" for making informed judgements about retrieved information, with wariness about the validity and completeness of internet sources. Significantly, as stated by Bawden (2008: 20), an awareness of the value of traditional tools in conjunction with networked media was emphasized.

A comprehensive overview of the development of digital literacy can be found in Bawden (2008: 21) from its origins in computer literacy or IT literacy to information literacy in the 1980's and beyond. Central to information literacy was the notion that digital literacy is not simply concerned with technical skills and the ability to use computers. This became a key tenet of Gilster (1997: 15) who noted that it is about "mastering ideas, not keystrokes". Thus, digital literacy can be defined as one of the survival skills in the digital era. It constitutes a system of skills and strategies used by learners and users in digital environments (Eshet-Alkalai 2004: 102). Bawden (2008: 28) continued by propounding "four general agreed components of digital literacy": 1. underpinnings, that is literacy per se, and computer and ICT literacy; 2. background knowledge: a knowledge of the new world of information and the nature of information resources; 3 . central competencies (reading and understanding digital and non-digital formats; creating and communicating digital information; evaluation of information; knowledge assembly; information literacy and media literacy); and finally, 4. attitudes and perspectives.

An important view of digital literacy for our research comes from Lankshear and Knobel (2006), who suggested that "[d]efinitions of digital literacy are of two main kinds: conceptual definitions and standardized sets of operations intended to provide national and international normalizations of digital literacy" (Lankshear \& Knobel 2006: 12). In addition to defining what digital literacy is, there is also the need to look at how these definitions are applied in the real world. White (2015: 28) defines digital practices in the following way: "the study of how individuals and groups use and apply digital technologies to everyday tasks, learning and work ..." and refers to two models for examining digital practice: those of White and Le Cornu (2011) with their "visitors" and "residents" paradigm and Sharpe and Beetham (2010).

Sharpe and Beetham (2010) suggest a pyramid model where each level represents part of the process involved when individuals engage with digital literacy: access and awareness, skills, practices and identity. Sharpe and Beetham's model has been incorporated by the Joint Information Systems Committee (Jisc 2018) and expanded into a detailed seven-element developmental framework and then later 
into a framework consisting of six elements of not simply digital literacy, but digital literacies in the plural: 1) information, data and media literacies, 2) digital creation, innovation and scholarship, 3) digital identity and wellbeing, 4) communication, collaboration and participation, 5) digital learning and self development, and finally 6) ICT proficiency linking the elements together. This six-element framework was used as the basis for the survey of Finnish language centres in January 2017, reported in the present study.

\subsection{Surveying digital competences}

In order to gain an overview of teacher digital literacy, it is possible to garner information from two directions: firstly from the teachers themselves, but also from the students who share the same working space with them. There is a long history of research on student perceptions of and wishes into how digital aspects could or should be incorporated into their studies. The series of ECAR surveys (for example, Kvavik \& Caruso 2005; Brooks \& Pomeranz 2017) have recorded the changing interests of students in higher education. They show the increasing expectations higher education students have in terms of the use of digital implementation with a year-on-year rise in the popularity of blended courses (see also The New Media Consortium 2017). In Finland, studies carried out by Jalkanen and Taalas (2013) and Mutta et al. (2017) have included questions related to student digital practices. Jalkanen and Taalas (2013: 86) pointed to the previously noted ubiquity of digital tools in studies and stressed the need for students to be guided to find the most suitable digital tools. Mutta et al. (2017: 195) found that students were positive about the use of technology in a formal environment when teachers were competent in the use of relevant digital tools. Thus, whilst these surveys dealt with student rather than teacher perceptions, they point very clearly to the digital demands being currently placed on teachers in tertiary education by their students. For language teachers in a university setting, knowledge of digital literacy has become in practice obligatory.

This need for teachers' digital competence has been noted regularly in the literature (Krumsvik 2008; Stickler \& Hampel 2015), and some studies have dealt directly with teachers' digital attitudes and/or competence. A recent survey carried out by Milliner et al. (2016) examined the digital literacy of language teachers in tertiary education. In this survey that partly mirrors the 2digi survey, the authors attempted to discover the overall level of teachers' digital literacy. Milliner et al. (2016) wanted to find areas where teachers still need help, but also how well teachers can perform in a technology-rich environment. However, unlike in the present study, their interpretation of digital literacy leant heavily on the practical "competencies" of Bawden mentioned earlier and did not explore it as a concept in itself. In Finland, a recent survey was carried out by the Trade Union of Education (OAJ) on the digitalization of teaching at all levels of education (Hietikko et al. 2016). 
The results of the survey showed that teachers in general were positive towards this process, but that tertiary level teachers especially expressed fears about teaching becoming more shallow as a result (Hietikko et al. 2016: 9).

\section{Materials and methods}

The methodology used for the original 2digi study was questionnaire-based and made use of the Jisc Example Teacher Profile and the Jisc Digital Literacies Development Framework. Sharpe and Beetham's (2010) pyramid was used as the basis to develop the main questions (see Appendix 1): what functional access do teachers have, how do they evaluate their own and their colleagues' current digital skills, what do they perceive digital literacy to be, how far it has been developed in their curricula and what pedagogical practices are already in place. The questionnaire firstly evaluated respondents' functional access; that is, what digital tools are available in their daily working life. Their digital skills were then noted by using the "I can" statements of the Jisc matrices. The second half of the questionnaire asked respondents to evaluate their own and their colleagues' knowledge of what they consider digital literacy to be. Finally, respondents were asked to analyze how far digital literacy has penetrated curricula design and what pedagogical approaches have been used.

The survey was written in English using Webropol 2.0, translated into Finnish and distributed to all Finnish language centres in January 2017. The survey was open 27.1.2017-6.2.2017. The question types consisted of multiple choice questions (yes/ no/not sure), open questions for more reflective issues and a variety of statements to be evaluated with a Likert scale of $1-5$. One completion reminder was sent four days before the deadline date. In total, 104 replies were received from twelve different language centres with a response rate of approximately $20 \%$ (104/521). Replies were then analyzed both quantitatively and qualitatively. The qualitative analysis was carried out in part by analyzing the subjects' view on what they considered digital literacy to be by using Bawden's (2008) four elements of digital literacy and assigning each answer to one or more of the elements.

This same 2digi survey was then used in March 2017 as the basis for designing a survey for another target group: language teachers at the universities of applied sciences. Some background questions were added to this second version, and the format of the survey was different, but the contents of the questions and the scales used were the same, as from the outset the idea was that the results from these two surveys could be comparatively studied. This survey was written only in Finnish.

A link to the Webropol survey was sent to all universities of applied sciences 10.4.2017, and a reminder was sent before the survey was closed 12.5.2017. 113 language teachers from 21 universities of applied sciences took part in the survey. There is no current data available about the exact number of language teachers 
working at the universities of applied sciences, but the response rate can be estimated to be approximately the same as for the university language centres (113/ about 600 teachers). The sample can also be considered representative, because the respondents consisted of teachers of nine different languages and were teaching in all eight fields of studies offered at the universities of applied sciences. Most of the teachers had more than 15 years of teaching experience, and ages ranged between 40 and 60 years old. This background data was not used in the analysis of the results for this article, however, because there was no similar data available from the 2 digi surveys.

\section{$4 \quad$ Results}

We now present the results of our surveys. We have analysed separately the replies from the UAS and ULC language teachers and compare these results in terms of the following aspects: digital elements in teaching (section 4.1), knowledge of digital literacy (section 4.2), application of digital literacy in curriculum work (section 4.3), individual digital skills (section 4.4) and development needs for the future (section 4.5). We have also compared the English and the Finnish replies from the university language centre teachers in some cases where we found interesting differences.

\subsection{Digital elements in teaching}

Approximately half of the teachers both at the universities of applied sciences (UAS) and at the language centres of universities (ULC) totally agreed that it is essential to have a digital element in their teaching (see Figure 1). $24-29 \%$ of them partly agreed, and $14-20 \%$ were not sure about their opinion. A small number of teachers fully disagreed with the statement.

Teachers were asked if they had access to digital devices in their teaching and if they were actually using these devices. As can be seen in Table 1, the only device all the teachers had access to was a computer (only one UAS teacher was not using one). Most of the teachers also had access to mobile phones, but only $24-35 \%$ of them actually used them. Surprisingly, document cameras were, in fact, used more often. About $40 \%$ of the teachers had access to iPad or tablet use in their teaching, but only $24-28 \%$ of them used it. 


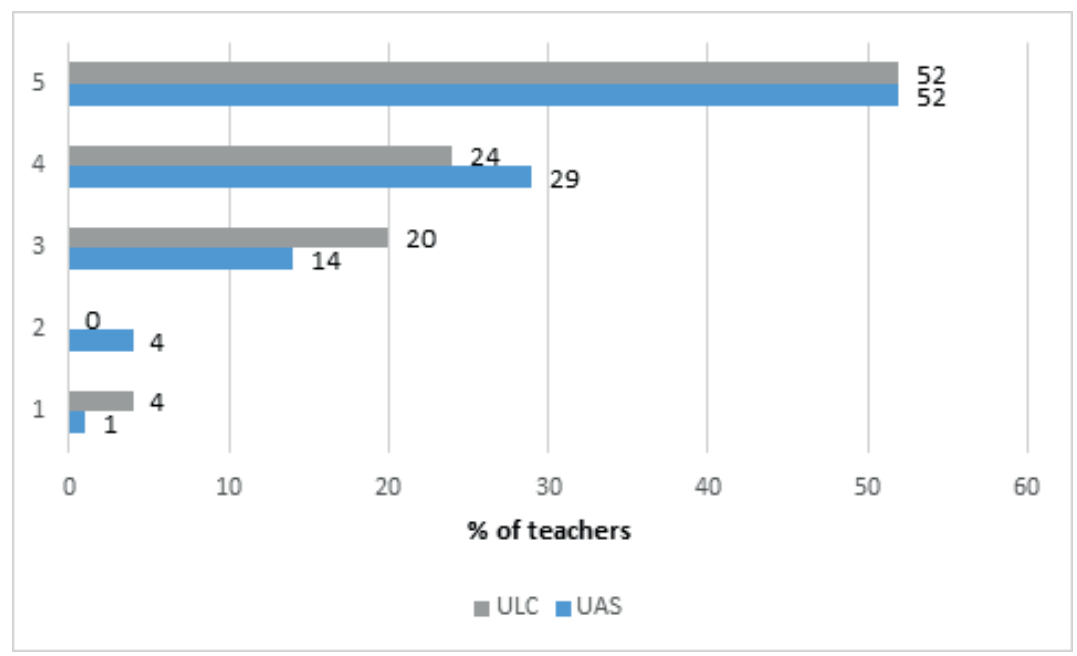

FIGURE 1. Having a digital element in my teaching is essential (\% of language teachers, $\mathrm{n}=104$ ULC, $\mathrm{n}=113$ UAS; $5=$ =agree fully, 1 =disagree fully).

TABLE 1. Access to and actual usage of digital devices (\% of language teachers).

\begin{tabular}{lcc|cc}
\hline Digital device & \multicolumn{2}{c|}{ UAS $(\mathrm{n}=113)$} & \multicolumn{2}{c}{ ULC $(\mathrm{n}=104)$} \\
& Access to & Actual usage & Access to & Actual usage \\
\hline computer & 100 & 98 & 100 & 100 \\
mobile phone & 72 & 35 & 63 & 24 \\
document camera & 46 & 38 & 62 & 38 \\
iPad/tablet & 38 & 24 & 44 & 28 \\
video camera & 33 & 17 & 56 & 22 \\
$\begin{array}{l}\text { Apple TV or other streaming } \\
\text { device }\end{array}$ & 9 & 5 & 24 & 11 \\
\hline
\end{tabular}

The most notable differences between the ULC and UAS teachers could be seen in access to document and video cameras and Apple TVs: the ULC teachers had more access to these devices than the UAS teachers.

\subsection{The concept of digital literacy}

$52 \%$ of the UAS teachers believed that they knew what digital literacy means, whereas half of the teachers with Finnish replies from ULC replied that they were not sure what digital literacy means. Interestingly, there was a clear difference when this result was compared to the replies from the English version of the questionnaire in 
ULC where $70 \%$ of teachers felt they were sure about the meaning of digital literacy (see Figure 2).

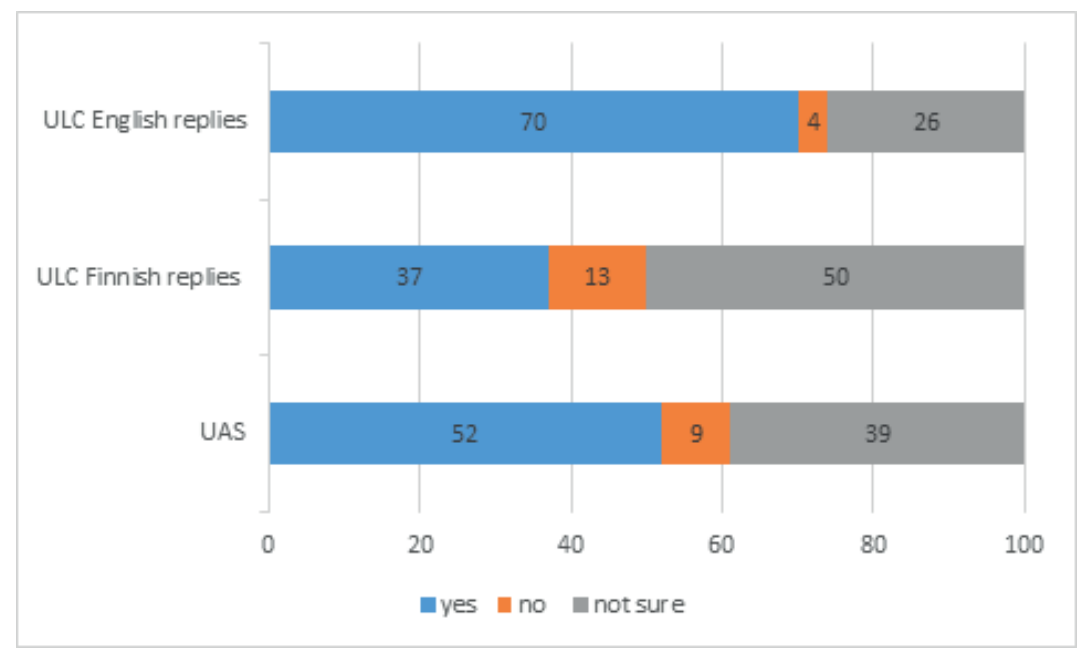

FIGURE 2. Understanding of the concept of digital literacy (\% of language teachers; $n=25$ ULC English, $n=84$ ULC Finnish, $n=104$ UAS).

In the initial university survey, answers to the English survey showed clear divergence to the answers given in Finnish: $70 \%$ to $37 \%$ in terms of how clear digital literacy is and $26 \%$ to $50 \%$ in regard of how unclear it is. These results may be related to the fact that digital literacy is a concept still firmly embedded in the English language.

$70-83 \%$ of the teachers said that they were interested in the concept of digital literacy (see Table 2). However, only $66 \%$ of ULC teachers indicated that they had discussed digital literacy at their university, whereas $90 \%$ of the UAS teachers answered that they had done so. $65 \%$ of the ULC teachers also felt unsure whether their colleagues understood the concept of digital literacy, as opposed to $42 \%$ of the UAS teachers. Most of the UAS teachers (52\%) thought that their colleagues understood the concept. 
TABLE 2. Teachers' opinions about selected statements (\% of teachers).

\begin{tabular}{|c|c|c|c|c|c|c|}
\hline \multirow[t]{2}{*}{ Statement } & \multicolumn{3}{|c|}{$\begin{array}{c}\text { UAS } \\
N=113\end{array}$} & \multicolumn{3}{|c|}{$\begin{array}{c}\text { ULC } \\
N=104\end{array}$} \\
\hline & yes & no & $\begin{array}{l}\text { not } \\
\text { sure }\end{array}$ & yes & no & $\begin{array}{l}\text { not } \\
\text { sure }\end{array}$ \\
\hline $\begin{array}{l}\text { The concept of digital literacy interests } \\
\text { me. }\end{array}$ & 83 & 6 & 11 & 70 & 9 & 21 \\
\hline $\begin{array}{l}\text { We have discussed digital literacy in our } \\
\text { university. }\end{array}$ & 93 & 1 & 6 & 66 & 8 & 25 \\
\hline $\begin{array}{l}\text { My colleagues know and understand the } \\
\text { concept of digital literacy. }\end{array}$ & 52 & 5 & 42 & 34 & 1 & 65 \\
\hline
\end{tabular}

In terms of teachers' understanding of digital literacy (question 9, Appendix 1), the 2 digi study answers were categorized according to Bawden's (2008) four elements of digital literacy. The answers showed that teachers' perceptions of digital literacy focused most heavily on the very practical central competencies that they felt they and their students needed (see Figure 3).

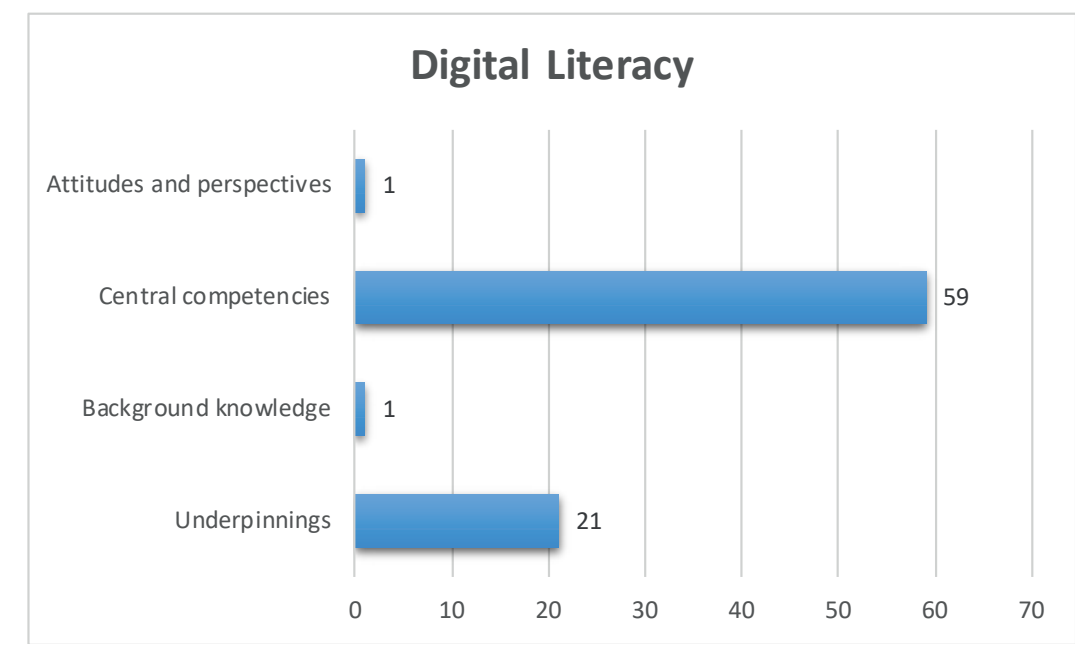

FIGURE 3. University language centre teachers' perceptions of digital literacy $(n=84)$.

The same tendencies could be seen in the answers of the UAS language teachers. Most of them mentioned the use of different tools and applications as central competencies as in the following examples.

Natural use of digital tools and making use of them in one's work, and understanding their use and pedagogical benefits. 
You can make use of technology in teaching, assessment and planning. You can teach your students how to use digital tools in teaching.

Varied, fluent and safe use of digital technology retrieving and handling knowledge, materials production and communication.

These examples were translated from the original Finnish answers to English by the authors.

\subsection{Digital literacy in curricula}

Results showed that teachers were encouraged to add digital literacy elements to their teaching both at universities and at universities of applied sciences (see Figure 4). About $90 \%$ also thought that technology was actually used to support students' learning and research. However, when it came to digital literacy in curricula, there seemed to be some differences between the two groups of teachers: at the universities of applied sciences digital literacy was mentioned more often in the curricula (46\%), compared to only $33 \%$ of the university language centres. Moreover, students' digital literacy was more frequently assessed as part of the curricula at the universities of applied sciences.

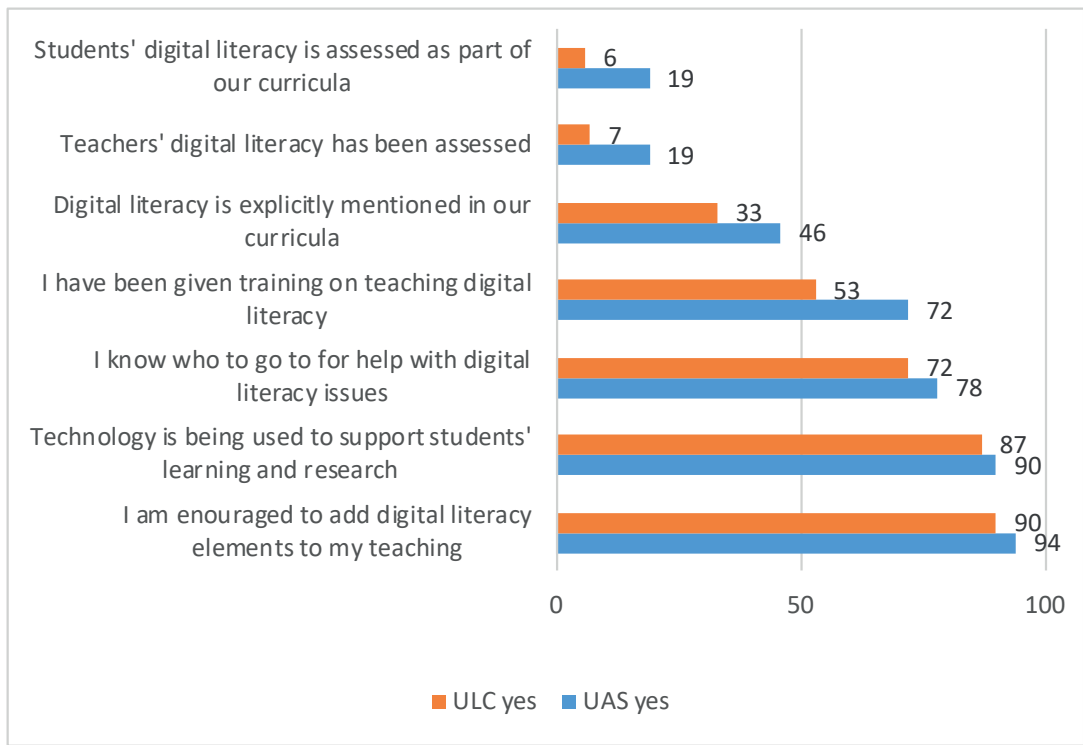

FIGURE 4. Digital literacy in curricula and teachers' perceptions ( $\%$ of language teachers; $n=113$ UAS, $n=104$ ULC). 
The differences were even more prominent regarding how many teachers had been given training in teaching digital literacy: $72 \%$ of the UAS teachers had participated in training, whereas only $53 \%$ of the ULC teachers had had that possibility. We found that teachers' digital literacy was seldom assessed: only the skills of $7 \%$ of the ULC teachers and $19 \%$ of the UAS teachers had been assessed. Finally, most of the teachers (72-78\%) knew whom to consult for help with digital literacy issues.

\subsection{Teachers' digital skills}

The teachers were also asked to assess their own digital skills. $30 \%$ of the ULC teachers who answered the English version of the survey assessed their digital skills to be at level 5 with the scale $1-5$, whereas only $8-11 \%$ of the teachers who answered the Finnish version thought their skills would be as good (see Figure 5). The most typical assessment was 4, both among UAS teachers and those ULC teachers who answered the English version of the survey. The ULC teachers who answered the Finnish version chose 3 and 4 almost as often.

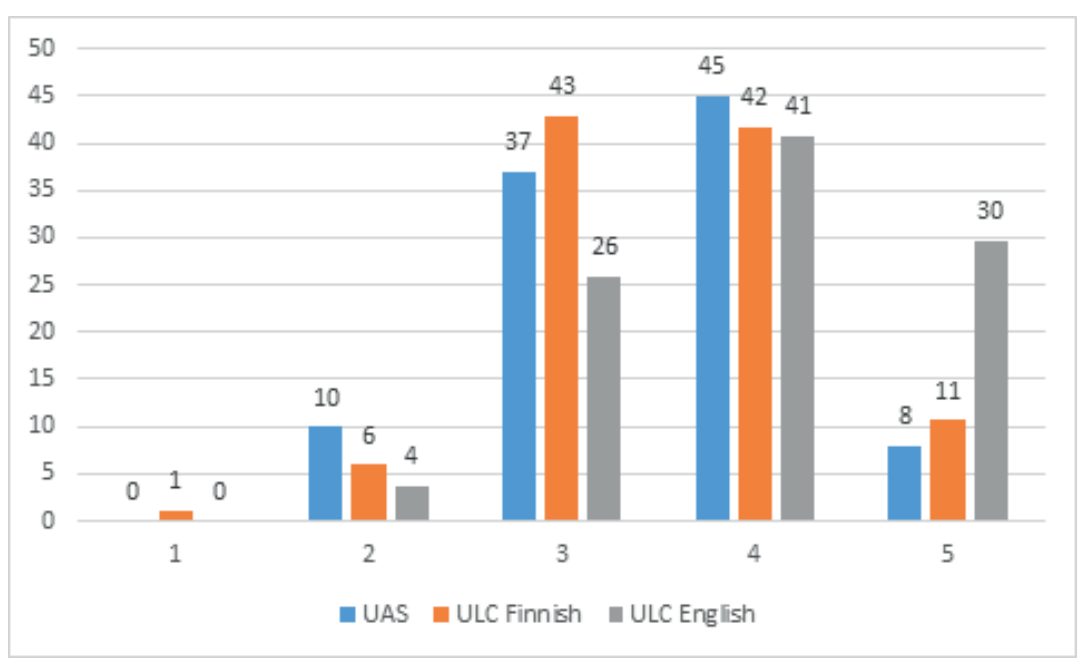

FIGURE 5. Teachers' self-assessment of digital skills (\% of the teachers; $n=113$ UAS, $n=84$ ULC Finnish, $\mathrm{n}=25$ ULC English).

Only a small number of teachers assessed their skills to be at levels 1-2. These results are in line with the survey carried out by Milliner et al. (2016), who found almost the same distribution of results on a four-point scale measuring teachers' self-perceived computer and internet literacy. 
The teachers were also asked to provide details about their skills with different digital technologies by responding to a number of "I can" statements on the scale 1-5 (1=poor, $5=$ very good). The averages of their answers are illustrated in Figure 6. The same tendency can also be seen here: the ULC teachers with English replies had the highest averages in all cases. The most remarkable difference was found in instructing the students to use digital tools: the teachers with English replies felt they had good skills $(4=$ good), whereas the teachers with Finnish replies and also the UAS teachers had an average at level 3.

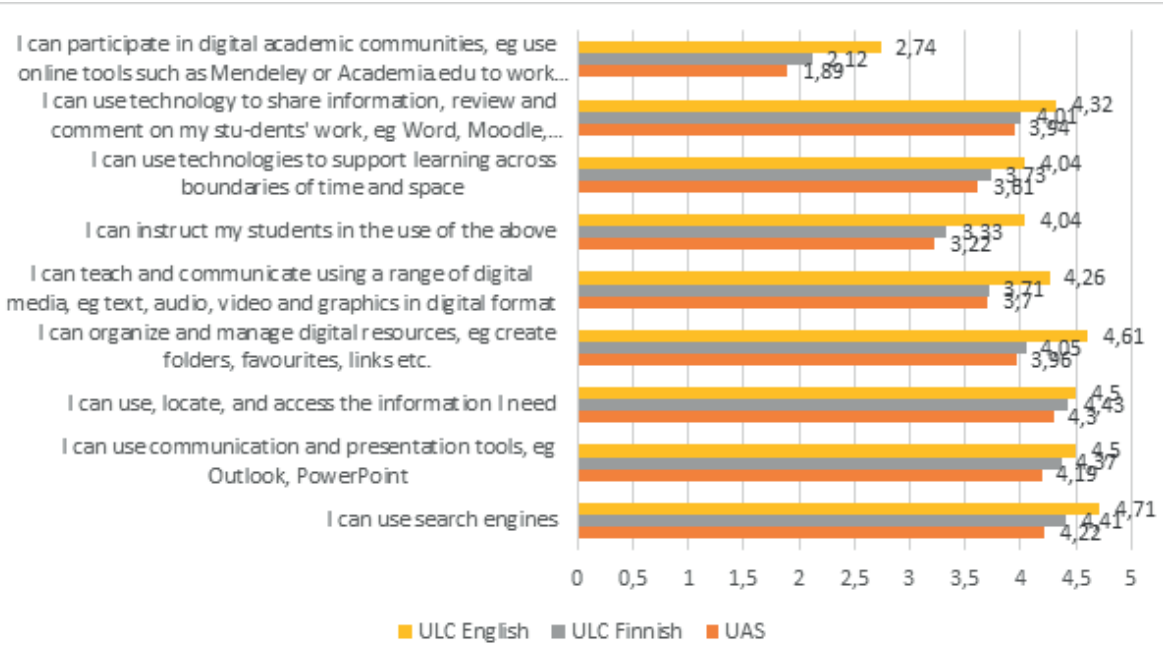

FIGURE 6. Averages of teachers' answers to "I can" statements ( $\mathrm{n}=113$ UAS, $\mathrm{n}=84$ ULC Finnish, $\mathrm{n}=25$ ULC English).

Clearly, the weakest skill common to all teachers was that of participating in digital communities, though teachers with English replies had a slightly higher average in this regard.

\subsection{Development needs in the future}

One of our key questions for the surveys and this article was how teachers viewed their development needs for the future. Thus, teachers were asked how important they thought a variety of steps would be in developing their own digital literacy skills in the future on a scale of $1-5$ ( $1=$ not important, $5=$ very important). The UAS teachers generally considered that all the above mentioned steps were more important when compared to the ULC teachers (see Figure 7). This difference between the teacher groups was clearest regarding the definition of digital literacy and developing basic ICT skills, which were both regarded as very important by the 
UAS teachers. The highest need for further training was expressed in both groups for pedagogical training in order to learn how to use digital technology in teaching.

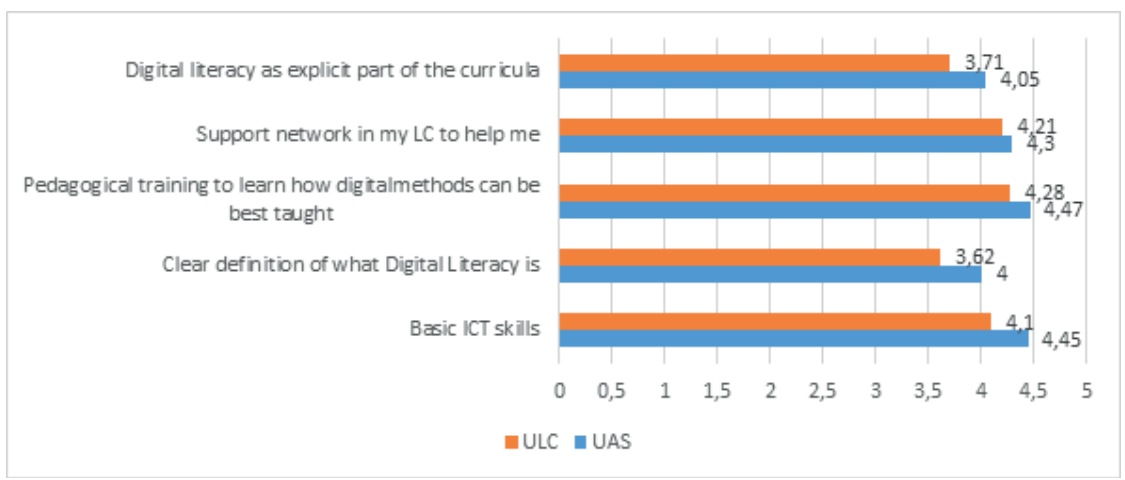

FIGURE 7. The importance of some developmental steps in the future (averages, $n=113$ UAS, $n=104$ UAS).

Teachers were also given the opportunity to comment on all these issues in their open answers. The same themes recurred in the open sections of both surveys with more time for taking part in training and learning to use different digital devices being the most popular. Examples are provided below:

Sufficient resources to develop and apply what one has learned at work.

There should be a dedicated person who can give support to teachers when there are digital problems, preferably face-to-face support.

Support from the work community and the organization in developing pedagogical skills in online / e-learning.

Sharing of pedagogically working solutions.

Technical support and guidance, pedagogical training and concrete examples, support from colleagues and the organization were also high on the list.

\section{Discussion}

In terms of our initial questions, we found that almost $80 \%$ of the language teachers both at UASs and ULCs considered the digital element in their teaching either important or very important. In their answers to our question of teachers' digital skills assessment, approximately 50\% assessed their own digital skills to be good or very good. However, only approximately $20 \%$ of the teachers answered the survey, 
so these results may well give too positive a picture of the real situation. It is possible that many teachers who are not so interested in digital literacy were among those who did not take part in this survey, although it was pointed out in the information letter that it would be important that all teachers with or without special interest in digital literacy would answer the questions.

As far as we know, these are the first surveys carried out where language teachers from university language centres and universities of applied sciences have answered the same set of questions. This facilitated, for the first time, a comparison between institutions in this regard. The results showed that firstly, the language teachers at the universities of applied sciences were more confident in their knowledge about the concept of digital literacy than the teachers at the university language centres who answered in Finnish. At the same time, the UAS teachers found it more important to define what digital literacy actually means. The UAS teachers also considered future training and help more important than their colleagues at the university language centres. This could partly be explained by the organizational differences: almost all the universities have a language centre, which is also responsible for giving this kind of support and training, whereas only a limited number of universities of applied sciences currently have this kind of centralized language training. It is more common that the language teachers work in the degree programs together with other teachers and that there is not so much cooperation between the language teachers. Despite this difference, teachers in both institutions focused on the same issues for future development: the need for time, pedagogical as well as technical training, and local support in both these aspects.

\section{Challenges and future developments}

Arguably, the most important aspect of this study was to facilitate the formulation of guidelines for future development. Thus, the results of the two surveys described in this article are not an end in themselves. They are being used to form the basis for a national-level strategy for furthering the digital literacy of language and communication teachers both in universities and universities of applied sciences. Teachers have indicated what help they need and they are remarkably similar in both the university setting and in universities of applied sciences. It is now up to the universities and universities of applied sciences to pay attention to what is needed at the personal, national and organizational level.

At the individual level, it is important for teachers to gain a clear understanding of digital literacy and its application in the classroom. It is also important that teachers' individual basic IT skills improve, empowering them to test different applications. In addition, it would be beneficial to collaborate more both with colleagues and with students and learn together, rather than struggle alone with different digital 
challenges (see also Jalkanen \& Taalas 2015: 183). In this way, teachers can perhaps better meet the challenges of building individual learning paths for students using digital media as a resource as suggested by Jalkanen and Taalas (2013: 86).

At the organizational level, the focus needs to be on maintaining and increasing support for developing basic ICT skills. An efficient form of support, also mentioned in the open answers in the surveys, is a combination of pedagogical and technical expertise, e.g. digimentors, digipedagogical experts. Moreover, it is important to encourage all teachers to recognize the need for continuous personal development and to reserve time for this. Our views thus echo the recommendations of Hietikko et al. (2016: 40) who stressed the continued long-term need for local teacher support and training. It should also be remembered that the individual and organizational levels are not mutually exclusive. Krumsvik's (2008: 288-289) study in Norwegian schools also concluded that whilst teachers should take responsibility for their own digital development, it needs to be supported at management level to create a caring and sharing environment.

At the national level, the primary concern should be to inform teachers in all types of institutions about the pedagogical underpinnings of teaching in a digital environment. In language and communication studies, digital literacy, its definition and the applications used need to be brought clearly and systematically into the curricula at the universities and at the universities of applied sciences. This would be a natural and necessary development of what has already taken place at the lower educational stages, i.e. primary, secondary and upper secondary education. We would also need more open forums for sharing and discussing good practices, pedagogical experiments and working applications. In addition, more research needs to be conducted into how different digital applications and methods affect learning.

Our study has shown that there is a high level of interest in digital issues among language and communication teachers in Finland. It has also shown that staff are encouraged to include digital elements in their teaching. Whilst more organizational assistance has been offered in this area in universities of applied sciences, increased support is still needed at the university language centres. It is also important that this assistance does not restrict itself to only the practical ICTbased skills; it is the pedagogical implications of teaching successfully in a digital environment that has alluded many teachers until now. The 2digi and DIGIJOUJOU projects, it is hoped, will go some way to improving this situation and help provide teachers with the support and knowledge they need for the 21 st century classroom. 


\section{References}

Ala-Mutka, K. 2011. Mapping digital competence: towards a conceptual understanding. JRC technical notes. Luxembourg: Publications Office of the European Union. http://ftp. jrc.es/EURdoc/JRC67075_TN.pdf [accessed 6 July 2018].

Bawden, D. 2008. Origins and concepts in digital literacy. In C. Lankshear \& M. Knobel (eds) Digital literacies: concepts, policies and practices. New York, NY: Peter Lang, 17-32.

Binkley, M., O. Erstad, J. Herman, S. Raizen, M. Ripley, M. Miller-Ricci \& M. Rumble 2012. Defining twenty-first century skills. In P. Griffin, B. McGaw \& E. Care (eds) Assessment and teaching of 21st century skills. London: Springer, 17-66. https://doi. org/10.1007/978-94-007-2324-5.

Brooks, D. \& J. Pomerantz 2017. ECAR study of undergraduate students and information technology, 2017. Research report. Louisville, CO: ECAR.

Davies, A., D. Fidler \& M. Gorbis 2011. Future work skills 2020. Palo Alto, CA: Institute for the Future for University of Phoenix Research Institute. http://www.iftf.org/uploads/ media/SR-1382A_UPRI_future_work_skills_sm.pdf [accessed 6 July 2018].

DIGIJOUJOU 2018. The DIGIJOUJOU project. http://digijoujou.blogspot.com/ [accessed 10 October 2018].

Eshet-Alkalai, Y. 2004. Digital literacy: a conceptual framework for survival skills in the digital era. Journal of Educational Multimedia and Hypermedia, 13 (1), 93-106. https://www. learntechlib.org/primary/p/4793/.

FINELC 2018. The network of Finnish university language centres. http://finelc.languages.fi/ [accessed 10 October 2018].

Gilster, P. 1997. Digital literacy. New York, NY: Wiley.

Hietikko, P., V. Ilves \& J. Salo 2016. Askelmerkit digiloikkaan. OAJ:n julkaisusarja 3:2016. Helsinki: Opetusalan ammattijärjestö. https://www.oaj.fi/cs/oaj/OAJn\%20 askelmerkit\%20digiloikkaan.

Jalkanen, J. \& P. Taalas 2013. Yliopisto-opiskelijoiden oppimisen maisemat: haasteita ja mahdollisuuksia kielenopetuksen kehittämiselle [University students' landscapes of learning: challenges and opportunities for the development of language teaching]. In T. Keisanen, E. Kärkkäinen, M. Rauniomaa, P. Siitonen \& M. Siromaa (eds) AFinLA-e: Soveltavan kielitieteen tutkimuksia 5. Jyväskylä: Finnish Association of Applied Linguistics AFinLA, 74-88. https://journal.fi/afinla/article/view/8740.

Jalkanen, J. \& P. Taalas 2015. Monimediaisen kielten opetuksen tutkimus: teknologian integroinnista pedagogiseen kehittämiseen [Research on multimodal language pedagogies: from integrating technology to pedagogical development]. In T. Jakonen, J. Jalkanen, T. Paakkinen \& M. Suni (eds) Kielen oppimisen virtauksia - Flows of language learning. AFinLA yearbook 2015. Jyväskylä: Finnish Association of Applied Linguistics AFinLA, 172-186. https://journal.fi/afinlavk/article/view/49416.

Joint Information Systems Committee (Jisc) 2018. https://www.jisc.ac.uk/ [accessed 6 July 2018].

Krumsvik, R. 2008. Situated learning and teachers' digital competence. Education and Information Technologies, 13, 279-290. https://doi.org/10.1007/s10639-008-9069-5.

Kvavik, R. \& J. Caruso 2005. ECAR study of students and information technology 2005: convenience, connection, control, and learning. Volume 6. Boulder, CO: Educause.

Lankshear, C. \& M. Knobel 2006. Digital literacy and digital literacies: policy, pedagogy and research considerations for education. Nordic Journal of Digital Literacy, 1, 12-24. https://www.idunn.no/dk/2006/01/digital_literacy_and_digital_literacies_-_policy_ pedagogy_and_research_cons. 
Milliner, B., T. Cote \& E. Ogane 2016. Tertiary EFL teachers' digital literacy: is CALL training still needed? Paper presented at EUROCALL, August 2016. https://www.researchgate. net/publication/307359355_Tertiary_EFL_Teachers\%27_Digital_Literacy_Is_CALL_ training_still_needed [accessed 30 May 2018].

Ministry of Education and Culture 2018. Policy and development in higher education and science. http://minedu.fi/en/policy-and-development-in-higher-education-andscience [accessed 13 February 2018].

Mutta M., P. Lintunen \& S. Pelttari 2017. Kielitaito ja informaalin oppimisen kontekstit: kielten opiskelijoiden ja yhteiskuntatieteilijöiden käsityksiä kielitaidosta ja teknologioiden hyödyntämisestä oppimisen tukena [Language skills and the contexts of informal learning: language students' and political science students' perceptions of language skills and the use of technologies to support learning]. In S. Latomaa, E. Luukka \& N. Lilja (eds) Kielitietoisuus eriarvoistuvassa yhteiskunnassa - Language awareness in an increasingly unequal society. AFinLA yearbook 2017. Jyväskylä: Finnish Association of Applied Linguistics AFinLA, 181-200. https://journal.fi/afinlavk/article/view/60777.

Sharpe, R. \& H. Beetham 2010. Understanding students' uses of technology for learning: towards creative appropriation. In R. Sharpe, H. Beetham \& S. de Freitas (eds) Rethinking learning for the digital age: how learners shape their experiences. London: Routledge, 85-99.

Stanley, G. 2013. Language learning with technology. Ideas for integrating technology in the classroom. Cambridge: Cambridge University Press.

Stickler, U. \& R. Hampel 2015. Transforming teaching: new skills for online language learning spaces. In R. Hampel \& U. Stickler (eds) Developing online language teaching. Research-based pedagogies and reflective practices. Basingstoke: Palgrave Macmillan, 63-77.

The New Media Consortium 2017. NMC horizon report 2017, higher education edition. http:// cdn.nmc.org/media/2017-nmc-horizon-report-he-EN.pdf [accessed 17 May 2018].

2digi 2018. The 2digi project. https://2digi.languages.fi/ [accessed 10 October 2018].

Universities Act 2009. Universities Act 558/2009 (Amendments up to 644/2016 included). http://www.finlex.fi/en/laki/kaannokset/2009/en20090558.pdf.

Universities of Applied Sciences Act 2014. Universities of Applied Sciences Act 932/2014 (Amendments up to 563/2016 included). http://www.finlex.fi/en/laki/ kaannokset/2014/en20140932.pdf.

Walker, A. \& G. White 2013. Technology enhanced language learning. Oxford: Oxford University Press.

White, D. \& A. Le Cornu 2011. Visitors and residents: a new typology for online engagement. First Monday, 16 (9). http://firstmonday.org/article/view/3171/3049.

White, J. 2015. Digital literacy skills for FE teachers. Los Angeles, CA: Sage.

World Economic Forum 2016. The global competitiveness report 2016-2017. Geneva: World Economic Forum. http://www3.weforum.org/docs/GCR2016-2017/05FullReport/ TheGlobalCompetitivenessReport2016-2017_FINAL.pdf [accessed 13 Feb. 2018]. 


\section{Appendix: The 2digi survey questionnaire}

A Likert scale of $1-5$ was used unless otherwise indicated: $1=$ negative $/ 5=$ positive.

1. Name of my Language Centre

2. I have access to the following for my teaching in my language centre. (Yes/No/Not sure)

- Computer

- iPad/tablet

- Apple TV or other streaming device

- Video camera

- Mobile phone

- Document camera

3. How well does your university network (ethernet/wifi) work)?

4. Having a digital element in my teaching is essential.

5. How would you evaluate your own digital skills in the classroom?

6. I regularly use the following hardware in my teaching

- Computer

- iPad/tablet

- Apple TV or other streaming device

- Video camera

- Mobile phone

- Document camera

7. Respond to the following 'I can' statements according to how you feel your own skills match the statements. $1=$ Poor $5=$ Very good.

- I can use search engines

- I can use communication and presentation tools, eg Outlook, PowerPoint

- I can use, locate, and access the information I need

- I can organize and manage digital resources, eg create folders, favourites, links etc.

- I can teach and communicate using a range of digital media, eg text, audio, video and graphics in digital format

- I can instruct my students in the use of the above

- I can use technologies to support learning across boundaries of time and space

- I can use technology to share information, review and comment on my students' work, eg Word, Moodle, Turnitln etc.

- I can participate in digital academic communities, eg use online tools such as Mendeley or Academia.edu to work collaboratively 
8. The concept of digital literacy is clear to me.

9. Could you say, briefly, what you think digital literacy is? (Open text)

10. The concept of digital literacy interests me.

11. Digital literacy been discussed/worked on in our language centre.

12. My colleagues know about and understand digital literacy.

13. Answer the following statements according how digital literacy is part of your Language Centre's curricula.

- Digital literacy is explicitly mentioned in our curricula

- I am encouraged to add digital literacy elements to my teaching

- I have been given training on teaching digital literacy

- Teachers' digital literacy has been assessed

- Students' digital literacy is assessed as part of our curricula

- I know who to go to for help with digital literacy issues

- Technology is being used to support students' learning and research

14. What pedagogical approaches to digital practices are in use now in your language centre and how do they facilitate digital literacy? (Open text)

15. For the future, mark how important you feel the following would be to develop your digital literacy skills. $1=$ not important, $5=$ very important.

- Clear definition of what Digital Literacy is

- Pedagogical training to learn how digital methods can be best taught

- Support network in my LC to help me

- Digital literacy as explicit part of the curricula

16. Something else you would like to happen in the future to help you with your digital literacy skills. (Open text)

17. Please write any comments you have here. (Open text) 